\title{
Resetting the African Smallholder Farming System: Potentials to Cope with Climate Change
}

\author{
Bernhard Freyer and Jim Bingen
}

\section{Contents}

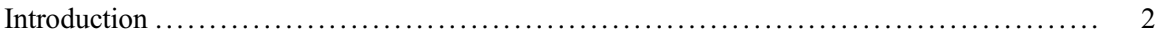

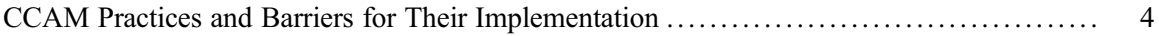

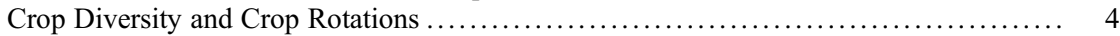

Mulching Strategies and Green Manure Cover Crops ............................ 6

Farm Yard Manure ...................................................... 8

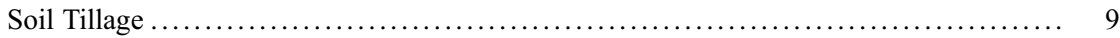

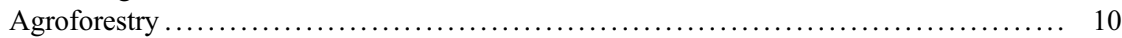

(Silvo-) Pastoral Systems ............................................... 10

Impact of Arable and Plant Cultivation Methods on $\mathrm{pH}$ Regulation ................... 11

Cattle, Dairy, Sheep, and Goat Systems ...................................... 12

Agricultural Production Systems Contributions to CCAM ........................... 12

Sustainable Intensification - Some Terminological Clarifications ................... 12

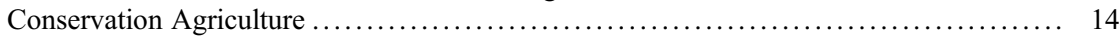

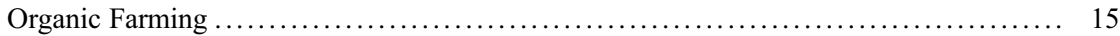

This chapter was previously published non-open access with exclusive rights reserved by the Publisher. It has been changed retrospectively to open access under a CC BY 4.0 license and the copyright holder is "The Author(s)". For further details, please see the license information at the end of the chapter.

B. Freyer $(\triangle)$

Division of Organic Farming, University of Natural Resources and Life Sciences (BOKU), Vienna, Austria

e-mail: bernhard.freyer@boku.ac.at

J. Bingen

Michigan State University (MSU), East Lansing, MI, USA

e-mail: bingen@msu.edu 


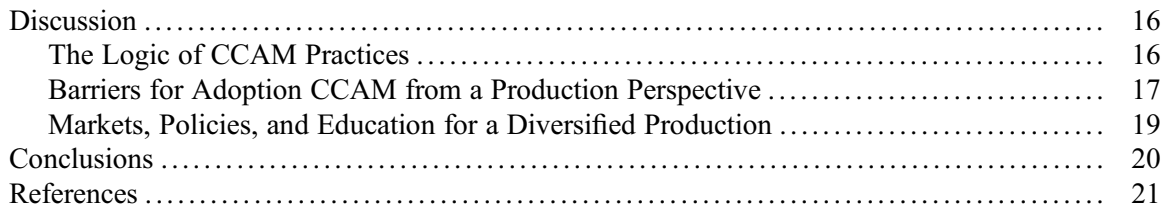

\section{Abstract}

Agricultural production systems, for example, conservation agriculture, climate smart agriculture, organic agriculture, sustainable landuse management, and others, summarized under the term "sustainable intensification," have been introduced in African countries to increase productivity and to adapt/mitigate CC (CCAM). But the productivity of smallholder farming systems in Africa remains low. High erosion, contaminated water, threatened human health, reduced soil water, and natural resources functionality, that is, ecosystems services, and decreased biodiversity dominate. Low support in the farm environment is also responsible for this situation.

It is hypothesized, based on the huge body of literature on CCAM, that the implementation of already existing arable and plant cultivation methods like crop diversity, alley crops, forage legume-based crop rotations, mulching, organic matter recycling, and reduced tillage intensity will increase CCAM performance and also farm productivity and income. Based on a brief analysis of CCAM relevant arable and plant cultivation methods and agricultural production systems potentials and challenges, this chapter offers guidance for further transforming climate robust African farming systems.

\section{Keywords}

Agricultural production systems · Arable and plant cultivation methods - Climate change adaptation and mitigation $\cdot$ Institutional environment $\cdot$ Smallholder farmers practices in Africa

\section{Introduction}

In this brief review, the discussion focuses on factors making smallholder farmers vulnerable to $\mathrm{CC}$ induced drought and floods and how they are able to cope with $\mathrm{CC}$. The chapter refers to the farms internal management, the relevance of the diverse arable, and plant cultivation methods that are differently organized and highlighted in today's agricultural production systems, which might contribute to adapt/mitigate climate change (CCAM), and how the institutional environment impacts a farmer's capacity to apply CCAM.

This chapter summarizes contributions to CCAM with reference to the diverse mixed farming systems in East Africa. This region is so far of interest as it entails a broad range of African farming systems. Those farming systems with an annual 
rainfall between approx. $800 \mathrm{~mm}$ and $2.000 \mathrm{~mm}$, annual or bi-annual rainfall patterns, and farm sizes between approx. 0.5 and 2.0 ha have been selected. With that the study excludes farming systems from mainly drought regions that however are asking for partly different farming solutions, which would open an additional chapter to discuss. So far, the review will offer a part of the whole picture on farm internal management strategies and relevant environmental (institutional) conditions specifically under East African conditions.

There is evidence that specifically Africans agricultural systems are challenged by climate change (IPCC 2018). To reach the SDG2 targets in the next decade, investment costs to reduce hunger in Africa for the next decade are tremendous (Mason-D'Croz et al. 2019). Such future pictures are based on mainstream agricultural practices, combined with all kinds of single agricultural practices, borrowed from latest discussed agricultural production systems (Gonzalez-Sanchez et al. 2019; Porter et al. 2019; Senyolo et al. 2018; Zougmoré et al. 2018).

The hypothesis, which is framing the analysis, argues that the systemic implementation of already existing arable and plant cultivation methods like crop diversity, alley crops, forage legume-based crop rotations, mulching, organic matter recycling, and reduced tillage intensity will increase CCAM performance and also farm productivity, and as a consequence also the income. The majority of recommendations to cope with $\mathrm{CC}$ on smallholder farms commonly involve single methods, such as diversified crop rotations, intercropping, relay cropping, alley cropping and silvo-pastoral systems, compost and manure management, $\mathrm{pH}$ regulation, mulching, and low tillage intensity. These methods are summarized as arable and plant cultivation methods, but are also discussed as "agroecological" methods. If properly managed, these methods can increase biodiversity and biomass production; close carbon and nutrient cycles, as well as optimize mineralization processes and increase carbon sequestration; decrease soil erosion; and optimize regulation of the micro- and mesoclimate and the water household. They can also be classified as the backbone of sustainable production, and as such, operate as ecosystems services. The single methods (crop rotation, mulching, ...) arise in different combinations and partly different "accentuations," in specific agricultural production methods described with the terms "climate smart agriculture, sustainable landuse management, or organic agriculture" and summarized under the term sustainable intensification.

Literature corpus on this topic is huge. Most of the methods are mentioned in the latest report on CC (The IPCC' Special Report on Climate Change and Land. What's in it for Africa? (Dupar $2019 \# 156$ ). But what is missing in this report is a systemic view and integration of the diverse practices that would make farming systems robust against $\mathrm{CC}$. In other words, to clearly indicate that adoption of farming systems is no longer the adequate reaction on the dramatic situation driven by CC. Instead, there is need for a huge transformation of farming systems as a whole.

For discussing the hypothesis, a selection of reviews and empirical studies seems adequate, using the terminology of arable and plant cultivation, that is, agroecology methods, and selected agricultural production systems (e.g., climate smart agriculture, conservation agriculture and others) within the context of CCAM as key words. 
Main literature was selected between the years 2010 and 2020 by Google scholar including reviewed papers and grey literature (Majumder 2015), to make visible how far in the last decade, where conservation agriculture, climate smart agriculture, agroecology, or sustainable intensification became prominent in the debate, CCAM was discussed. There are some exceptions, where identified literature informed about earlier relevant sources. Using cropping systems as an example, for all sections with a specific topic, search was defined as follows: Smallholder farming AND cropping systems AND Climate change AND Africa/Review AND Smallholder farming AND cropping systems AND Climate change AND Africa. Following a stepwise saturation in a certain field of knowledge, that is, explicit, reproducible, and leads to minimum bias, further papers that indicate mainly same messages have been excluded (Grant and Booth 2009).

A quantification of applied CCAM is critical due to the fact that there is huge diversity of agroecological conditions and farming practices and that there is no empirical basis available for making such an assessment. Instead, a qualitative assessment of the impact of CCAM methods is applied to primarily understand specific characteristics in their context (see the methodological approach chosen by Dale 2010). For that a set of methods both single arable and plant cultivation methods as well the agricultural production systems have been selected that are well known to be relevant for CCAM.

\section{CCAM Practices and Barriers for Their Implementation}

This section reviews the most relevant single methods, their potential to contribute to CCAM, and farm productivity, and the barriers that hinder farmers from implementing them are discussed. Drought adapted varieties, irrigation, and water management technologies are not mentioned specifically. It is assumed that they are part of any CCAM approach.

\section{Crop Diversity and Crop Rotations}

In many farming systems, crop diversity in crop rotations is low. Currently, maize is the dominant crop in most crop rotations in Africa. The other land is planted mainly with cereals, grain legumes, and root crops and in some cases intercropped maize and grain legumes (Table 1)(Rusinamhodzi et al. 2012). These one-sided systems, with open soils with low root $(<1 \mathrm{t} \mathrm{DM} \mathrm{ha-1} \mathrm{a-1)}$ and above ground biomass $(<2 \mathrm{t}$ DM ha-1 a-1), lead to highly vulnerable soils over the whole African continent, continuously loosing fertile soils and the capacity to store water and nutrients. The key crops for moving to higher CCAM relevant ecological functions of cropping systems are forage legumes and forage-grain legumes with high root $(>2 \mathrm{t} \mathrm{DM}$ ha-1 a-1) and above ground biomass ( $>4 \mathrm{t}$ DM ha-1 a-1) that currently can only be found in some selected regions in pure stands or in combination with maize, known as push and pull system. The latter is a combination of Maize with undersown/intercropped 


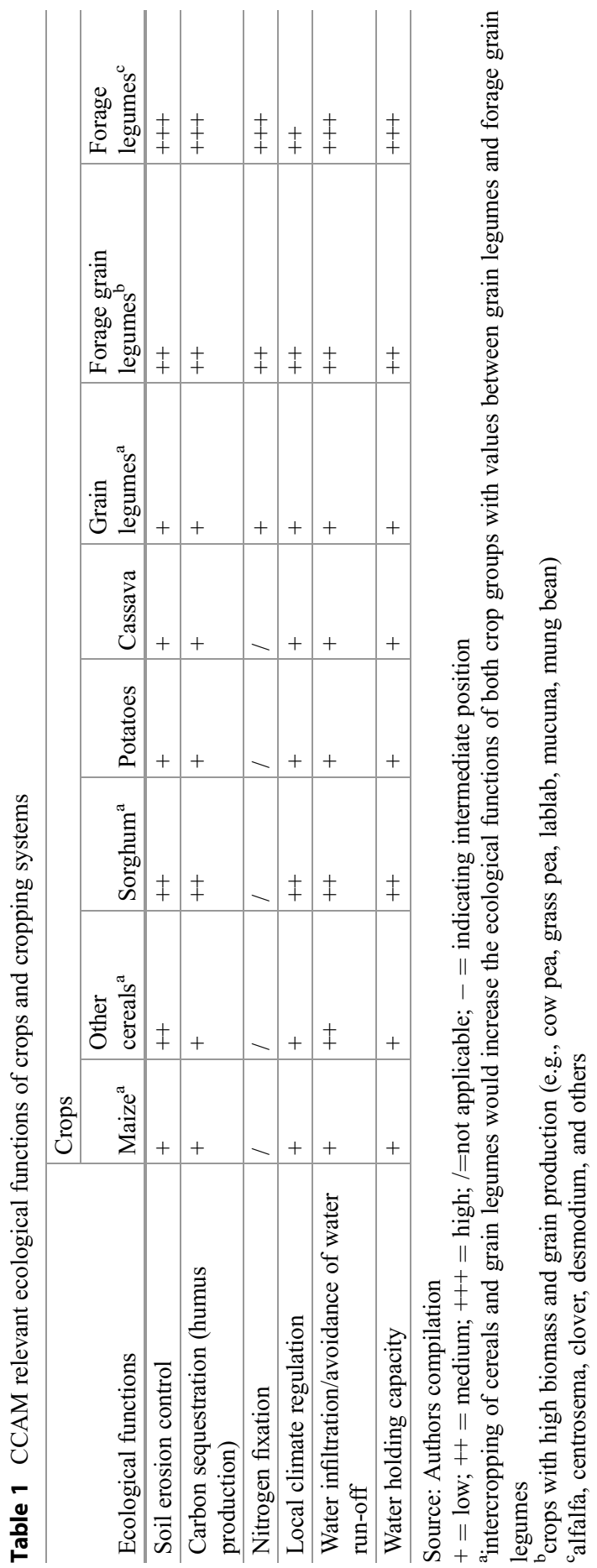


desmodium and Napier grass as a trap crop to control stemborer and striga, a chemical ecology-based integrated pest management technology (Khan et al. 2016).

The transformation of cropping systems towards forage legume-based systems can increase the potential of CCAM (Forage legumes $>$ Forage grain legumes $>$ Intercropping systems), through relatively high below (3-6 t DM ha-1 a-1) and above ground biomass (5-15 t DM ha-1 a-1) and nitrogen fixation (50-300 kg N ha1 a-1) of forage legumes (Kumar et al. 2018), efficiently reducing soil erosion (Sheaffer and Seguin 2003) and with positive impact on following cash crop yields (Traill et al. 2018). Nutrient acquisition and nutrient utilization are species and genotype specific and differ between crop families of grasses and legumes and between legumes (Gómez-Carabalí et al. 2010). Of relevance is the \% lignin, C:N ratio, (lignin + polyphenol): $\mathrm{N}$ and $\mathrm{C}$-to-N ratios (Thomas and Asakawa 1993). Evidence is also given that this crop group increases animal performance, where similarly the mentioned ratios are of relevance for the digestibility of forage legume feed (Schultze-Kraft et al. 2018).

The implementation of this crop group however is challenging for several reasons: the availability of seed material; the lack of knowledge about the potential impact of plant based nitrogen on the following crop performance; the idea that humans cannot eat forage legumes, and therefore cropping forage is a short-term loss of land for assuring food security, but one that overlooks the contribution of farm yard manure to increased crop yields as well as to the production of milk and meat.

It appears that forage legumes are not offered by either seed breeders, seed wholesalers, advisory services or researchers and policies, with some exceptions of selected species and regions. In the same way, farmers multiplication of seed material is an exception. The diversification of crop rotations with nonmainstream crops is limited because there is no demand by the markets, but also because of traditional food habits. Intercropping and relay cropping - two submethods of crop rotations - likewise can increase yield and income and are rarely implemented.

\section{Mulching Strategies and Green Manure Cover Crops}

It is commonly argued that mulch material contributes significantly to the ecological functions and CCAM (Table 2). Already small amounts of mulch material positively impact soil parameters (Mchunu et al. 2011). However, most smallholder farms have no left-over organic matter from their arable fields. All the straw and weeds are consumed by animals after harvest, or burned. As a result, soils are open and this contributes to a further loss of the first most fertile millimeter of humus via wind and water erosion, and leads to a continuous reduction of soil functions. Collecting mulch material outside the farm is for several reasons not a sustainable approach. First, in many regions, biomass is limited, but also requires significant labor, estimated to be 5 to 12 days per acre (Bunch 2017). Furthermore, it does not fit for a community or catchment approach if all farmers would collect biomass, competing also the feed demand of grazing animals, that are mainly far beyond the carrying capacity of the communities available pasture land (Wall 2017). Further 
Table 2 CCAM relevant ecological functions of agroecological practices

\begin{tabular}{|c|c|c|c|c|c|c|}
\hline \multirow[b]{2}{*}{$\begin{array}{l}\text { Ecological } \\
\text { functions }\end{array}$} & \multicolumn{6}{|c|}{ Agroecological methods (arable and plant cultivation methods) } \\
\hline & $\begin{array}{l}\text { Mulching } \\
\text { systems }\end{array}$ & $\begin{array}{l}\text { Green } \\
\text { manure } \\
\text { cover } \\
\text { crops }\end{array}$ & $\begin{array}{l}\text { Farm } \\
\text { yard } \\
\text { manure } \\
\text { types }^{\mathrm{a}}\end{array}$ & $\begin{array}{l}\text { Low } \\
\text { tillage } \\
\text { systems }\end{array}$ & $\begin{array}{l}\text { Agro- } \\
\text { forestry } \\
\text { systems }\end{array}$ & $\begin{array}{l}\text { Silvo- } \\
\text { pastoral } \\
\text { systems }\end{array}$ \\
\hline Soil erosion control & +++ & +++ & +-+++ & $\begin{array}{l}+-++ \\
+\end{array}$ & +++ & +++ \\
\hline $\begin{array}{l}\text { Carbon } \\
\text { sequestration } \\
\text { (humus production) }\end{array}$ & +-++ & +++ & +-++ & / & +++ & +++ \\
\hline $\begin{array}{l}\text { Reduction of soil } \\
\text { compaction }\end{array}$ & ++ & +++ & ++ & + & +++ & +++ \\
\hline Nitrogen fixation & / & /-+++ & l & / & +++ & +++ \\
\hline $\begin{array}{l}\text { Local climate } \\
\text { regulation }\end{array}$ & +-++ & +-++ & / & +-++ & +++ & +++ \\
\hline $\begin{array}{l}\text { Water infiltration, } \\
\text { i.e., avoidance of } \\
\text { water run of }\end{array}$ & +++ & +++ & ++ & +++ & +++ & +++ \\
\hline $\begin{array}{l}\text { Water holding } \\
\text { capacity }\end{array}$ & ++ & +++ & ++ & +++ & +++ & +++ \\
\hline $\begin{array}{l}\text { pH-regulation/ } \\
\text { increase of nutrient } \\
\text { availability }\end{array}$ & +++ & +++ & +++ & + & +++ & +++ \\
\hline $\begin{array}{l}\text { Nutrient/carbon } \\
\text { recycling }\end{array}$ & & & +++ & l & & \\
\hline - Spatial (field) & & & & & +++ & \\
\hline - Temporal (years) & +++ & +++ & & & +++ & \\
\hline $\begin{array}{l}\text { - Horizontal (soil } \\
\text { layer) }\end{array}$ & +++ & +++ & & & +++ & +++ \\
\hline
\end{tabular}

Source: Authors compilation

$+=$ low ++ = medium; $+++=$ high $;$ /=not applicable $;-=$ indicating intermediate position a including a broad range of types from stable manure up to liquid forms

relevant source for mulch material is branches from alley crops with an annual biomass productivity of 2 to $10 \mathrm{tDM}$ ha-1, dependent on the tree species, variety, as well as the planting density and well-managed ratooning (Wilson et al. 1986).

Green manure cover crops are mainly planted in the short rainy season and used also for food and feed purposes. Green manure cover crops (GMCC) include any species of plant, mainly leguminous crops, whether it is a tree, a bush, a climbing vine, a crawler, a grain legume, forage-grain legumes, or close to water a water born plant (Wall 2017). GMCC like Lablab beans (Dolichos lablab or Lablab purpureum), runner beans (Phaseolus coccineus), mucuna (Mucuna spp.), ratooned pigeon peas (Cajanus cajan), jack beans (Canavalia ensiformis), and many other GMCC species like tephrosia (Tephrosia vogelii or T. candida) produce high amounts of biomass and increase $\mathrm{C}$-sequestration (above and below ground 
biomass) (Branca et al. 2013; Hobbs and Govaerts 2010). Nitrogen fixation of leguminous crops varies in a broad range of approx. 80 and $250 \mathrm{~kg} \mathrm{~N}$ ha-1 a-1, according to species, variety, soil and climatic conditions, and crop management (Monegat 1991). Assuming a loss of 50\% via volatilization and use of grains (Bunch 2017), there are still more than $40 \mathrm{~kg}$ ha- $1 \mathrm{a}-1 \mathrm{~N}$ for the following crop with a reference value of $2 \mathrm{t}$ ha- 1 a- 1 wheat.

Seriously managed, CMCC, combined with minimum soil tillage, can reduce soil erosion by more than $90 \%$ (equivalent to a means of $850 \mathrm{~kg}$ ha-1organic matter, approximately $50 \mathrm{~kg}$ nitrogen ha- 1 and $8 \mathrm{~kg}$ phosphorus ha-1). GMCC provides nitrogen and offers weed control (Elwell and Stocking 1988), as well as other benefits, including the amelioration soil compacted (Scopel et al. 2004). But GMCC for compost or mulch is only partly a solution because farmers argue that all land should be used for food production, and this hinders them from investing in these crops, which asks for an answer. With forage grain legumes, an alternative exists that can fulfill both ecological functions, but also offer food and feed, and keep relevant parts of the fixed nitrogen in the field. Barriers to their implementation are costs (seeds) and lost harvest of a catch crop income. So, farmers often prefer intercropping of, or rotation with, grain legume crops rather than GMCC (Nandwa et al. 2011).

\section{Farm Yard Manure}

Farm yard manure (FYM), which is an un-normed mixture of dung, slurry, straw, and feed residues, is an organic material with many relevant ecological functions (Table 2) (Teenstra et al. 2015). FYM is potentially available on a farm for redistribution to the fields, if there is any form of zero grazing or animals fenced for certain times in a kraal. Systematically applied, FYM manure can increase biomass production by $100 \%$ (Ndambi et al. 2019). In many cases, its impact on yields is comparable with that of medium mineral fertilizer inputs; or the combination of $5 \mathrm{t}$ ha-1 FYM with $30 \mathrm{~kg} \mathrm{~N}$ ha-1 a-1 is able to produce equivalent maize yields in comparison with $200 \mathrm{~kg} \mathrm{~N}$ ha-1 a-1 (Achieng et al. 2010).

Practically each smallholder farm should have some FYM. One ox, one or two cows, and in some cases approx. Five sheep or goats and 10-20 chickens are a classical set of animals for a 1 ha farm. A tropical livestock unit is calculated with $250 \mathrm{~kg}$, which is $50 \%$ of the Western standard. Additional feed comes from communal pastures, feed along pathways, and from shrubs. Milk productivity with this feed is rather low (378.6 kg cow a-1 in 2018 in East Africa; http://www.fao.org/ faostat/en/\#data/QL). As a result, the production of farm yard manure is low as well as their nutrient content. Moreover, this limited manure production is often used for house construction or for cooking purposes. In addition, most farmers do not apply manure management practices, such as roofed animal housing, with water-proof floor or covering manure during storage in order to prevent large nutrient losses during manure storage, increasing greenhouse gas emissions, and reducing the 
quality of the manure as a fertilizer and its positive impacts on ecological factors, that is, contributions to CCAM (Ndambi et al. 2019).

To conclude, farm yard manure contribution in current smallholder systems to strengthen CCAM or productivity is seriously low or nonexistent. Hurdles for an adequate collection and use of FYM are lack of knowledge in general about the value of this organic matter, techniques for cut and carry feed, investment for zero grazing units, that is, kraal fencing, and techniques for the adequate distribution of the manure in the field. Furthermore, it seems neither in the focus of advisory services nor of research or policy agendas (ibid).

\section{Soil Tillage}

Soil tillage functions include, among others, to loosen the soil, to provide technical aid for in depth growth of roots, to homogeneously mix organic matter with the soil, and to prepare seed beds.

Current partly excessive soil tillage systems often lead to soil compaction, soil aggregate break down, soil dust, and rapidly decomposing organic matter. High rates of topsoil loss contribute to downstream sedimentation and degradation of local and regional water bodies (Tully et al. 2015). While soil compaction reduces the seedbed quality and thus hinders the germination of seeds, soil dust gets irreversibly lost via water and wind erosion. Thus, the current type of so-called plowing tillage systems in combination with maize dominated cropping systems weakens several ecological functions relevant for CCAM.

In general soil tillage systems follow a continuum from conventional inversion moldboard plow up to disc opener no-till planter into dead residue (Reicosky 2015). Alternative soil tillage systems have been developed over the years to reduce tillage intensity, including stubble mulching, to reduce or eliminate tillage, and to retain plant residue on the soil surface to alleviate wind and water erosion. These practices led to what became known as conservation tillage, culminating in no-till systems that avoid any soil disturbance. No-tillage, reduced-tillage, mulch-tillage, and striptillage are some of the diverse CA tillage approaches.

The combination of green mulch cover crops (GMCC) is expected to significantly increase ecological functions and contributions towards CCAM (Table 2). GMCCs can also control weeds by covering, that is, suppressing upcoming weeds. Potential yields through combining mulching and low soil tillage exceed 100\%. But it must be remembered that the quantity of additional organic carbon in the soil under no-till is relatively small. The main effects are relevant for other ecological functions and indirectly contribute to CCAM. Over the years it also has become evident, that after a period of low tillage interventions, this system must be interrupted for 1 year with a more intense tillage approach, in order to loosen natural soil compaction effects in the below ground, as well as to regulate the weed pressure (Powlson et al. 2014).

Soil tillage systems technologies with reduced intensity are only available in some regions and the optimal approach which depends on soil type, rainfall, share of skeleton, precrop and the following crop, as well as above ground biomass is still not 
identified for many agroecological situations. If not managed properly, nonadequate technique applied, and rotations without forage legumes, as well as limited or lack of mulch material, there is high risk of weed pressure, reduced crop yields. If weeds take over farmers then tend to misinterpret the approach increasing the application of fertilizer inputs and herbicides with negative environmental impact (Giller et al. 2011). A certain number of weeds however can provide also positive ecological functions, as discussed in OA (Hillocks 1998). Missing finances for the technical equipment and knowledge gaps might be other reasons for low adaptation rates of reduced tillage systems in Africa.

\section{Agroforestry}

The multifunctions of the diverse agroforestry systems are highly relevant for CCAM (Lasco et al. 2014), but also serve as forage or for other diverse purposes (fuel, construction, apiculture, food, forage), and provide positive contributions to reduce concentration of carbon dioxide (CO2) and other greenhouse gases (GHGs) (Awazi and Tchamba 2019) and to regulate microclimate (Mbow et al. 2014). Specifically, alley-crop-systems contribute to multiple ecological functions (Table 2). They contribute to a reduction of inorganic inputs (Wilkins 2008), to pest and disease control (Murthy et al. 2013), biodiversity (Murthy et al. 2016), and regulation of microclimate (Schroth et al. 1995). What makes them specifically attractive is their use of subsoil layer nutrients and water resources and photosynthesis above the main crops, well adapted to soil and climate conditions, simulating partly the original vegetation cover before once turned the land from natural forest to arable land.

Alley branches can be used directly as mulch, or as a protein feed for animals, filling the protein gap and leading to higher animal manure production. Trials of alley crops with rows all 4-8 $\mathrm{m}$ document the high positive impact on cash crop growth. A weakness in the majority of trials are monocropping alleys with an increased risk of pest and diseases, while diverse alley crops provide more resistance, multiple functions for arable pest and disease control, and a diversification of forage qualities and adaptability towards CC (e.g., Faidherbia spp.).

On smallholder farms, their integration is challenged if the land is scattered. Otherwise, already the limited area of the homestead would offer space for implementation. Biomass productive hedges are often not in place and also the technique of ratooning, for example, in case of pigeon pea, and other management practices are missing and are limited in biomass production with all its positive impact on CCAM. Further hurdles for smallholder farmers to integrate a diverse cropping scheme with alley crops are the limited availability of seedlings, lack of knowledge how to prune shrubs and to integrate into feed ratios, as well as investment costs and workload for their management. 


\section{(Silvo-) Pastoral Systems}

Pastoral systems are usually the backbone of animal systems. By nature, grassland is rich in root biomass and humus content is seriously higher than in arable systems with permanent soil tillage. However, in most African countries, pastures are overused, sward management is low, erosion is high, and productivity is not high enough to feed animals with energy and protein rich crops. Irreversible loss of land via erosive processes/land-slides is point on the agenda explaining the critical situation (Wynants et al. 2019). Land distribution and ownership patterns coupled with continuous fragmentations are further drivers of the current system and are challenging farmer towards sustainable grassland management (Tesfa and Mekuriaw 2014). Provision towards ecological functions, that is, contributions towards CCAM, is low if not negative.

Limited availability of seeds, lack of labor for establishing pasture systems, the cost of fencing and knowledge gaps, as well as missing management and knowledge at community level, as well as missing management at the community level, hinder and limit the production of pasture biomass and thus also their CCAM.

As an alternative silvopastoral system, a combination of pastures with leguminous shrubs and trees provide relevant contributions to ecological functions towards CCAM (Table 2) and an enormous increase of biomass production (Sarvade et al. 2019). The forage legume trees cover a high share of the protein gap limiting the animal production. Forage production can be seriously increased with a strong impact on the level of fattening and milk production and less GHG emissions per animal unit (Broom et al. 2013). For that grassland management needs to reorganize, including regulations for use, awareness on traditions, and fenced or otherwise controlled areas (Ochieng and Waiswa 2019).

\section{Impact of Arable and Plant Cultivation Methods on pH Regulation}

The $\mathrm{pH}$ of soils with substantial ecological functions and specifically high impact on biomass production is influenced by several of the arable and plant cultivation methods and therefore is summarized in this subsection. The $\mathrm{pH}$ of many East African soils is below 5.0, virtually no available phosphorus and toxic levels of aluminum (Bunch 2017) and therefore out of the optimum for a productive crop growth and biomass production, which is between 5.8 and 6.5 , while crop specific in a broader range. Mineralization processes, the optimal living conditions for microorganisms responsible for many soil functions, and growth conditions for crops are limited with low $\mathrm{pH}$, leading to lower crop yields, that is, less positive impact on CCAM. Under acid soil conditions, phosphorous is tied up in a short time and does not provide more than $0.5 \%$ soil phosphorous in forms that are available to plants. The general low $\mathrm{P}$ content of African soils increases the dilemma.

Mulch and compost material mainly from grass provide a large $\mathrm{C} / \mathrm{N}$ and therefore will not feed the crops. A high share of legumes instead offers a $\mathrm{C} / \mathrm{N}$ which boosts the growth of microorganism that are functioning as storage but also deliver nutrients 
towards crops through the decomposition of mulch material. Phosphorous becomes available as a slow floating source. Farm yard manure (approx. $\mathrm{pH} 7$ ), slurry (approx. $\mathrm{pH} 8$ ), and compost (approx. $>7 \mathrm{pH}$ ) with high $\mathrm{pH}$ values would positively influence nutrient availability and thus crop productivity. Current systems are lacking these effects due to the low availability of manure, slurry, and compost, which at least causes the inefficient landuse and low productivity of crop and animal production. Also, alley crops have the potential to increase the $\mathrm{pH}$ via litter fall, through re-transporting leached $\mathrm{Ca}$, however depends on tree species, and the presence of a subsoil of suitable quality, that is, clay enriched and with high $\mathrm{Ca}$ saturation (Vanlauwe et al. 2005).

Using lime is an option, so far locally available and transportable. But liming runs the risk of increased mineralization, that is, humus decomposition beyond what is needed, and there are cost factors.

\section{Cattle, Dairy, Sheep, and Goat Systems}

Ruminants play an intermediate position between crops and manure. Current feeding ratios are often of low quality. Overgrazed grassland, lack of any forage crops in the crop rotation, alley crops, and hybrid grasses (Pennisetum spp.; Brachiaria spp.) are the explaining factors. Specifically, protein deficits explain also the low performance in dairy production. Intense use of straw and stubble after crop harvests - a main forage source - reduces the humus level of soils, specifically if organic manure is not recirculated to the fields, which is in manure farms the practice and is increasing soil erosion. Without a forage management including access to water, positive outcomes of breeding programs cannot be transferred into practice. To add cereals or grain legumes in the feed ratios compete directly with human food and cannot be recommended as a key strategy, except the use of leftovers.

Ruminant demand for forage legumes, hybrid grasses (Ghimire et al. 2015), forage trees/alley crop branches (Franzel et al. 2014), and silvopastoral systems fit with the CCAM strategies, due to the fact that they all contribute to an increase of biomass production, farm internal nitrogen supply, and milk productivity per land unit. As a result, the organic manure nutrient content and quantities increase, which can serve as a valuable fertilizer for crops and for supporting soil functions.

\section{Agricultural Production Systems Contributions to CCAM}

This section first discusses diverse agricultural production methods and how they relate to each other in order to identify communalities and differences. As seen in the description of single CCAM relevant methods, they often refer to CA and OF. Table 3 informs about differences and similarities within an African context. 
Table 3 Assessment of CCAM relevant methods in CA and OA

\begin{tabular}{|c|c|c|}
\hline & \multicolumn{2}{|c|}{ Agricultural production methods } \\
\hline & Conservation agriculture & Organic agriculture \\
\hline \multicolumn{3}{|c|}{ CCAM relevant methods } \\
\hline Crop rotation & ++ & +++ \\
\hline Crop rotation & ++ & +++ \\
\hline - Forage legumes & ++-+++ & +++ \\
\hline - Relay cropping & +++ & +++ \\
\hline - Intercropping & +++ & +++ \\
\hline - Green manure & +++ & +++ \\
\hline Farmyard manure & +++ & +++ \\
\hline Compost & +++ & +++ \\
\hline Mulching & +++ & +++ \\
\hline Minimal tillage & +++ & +-++ \\
\hline Hybrid grass & ++ & ++ \\
\hline Alleys/hedges & +++ & +++ \\
\hline Silvopast. Systems & ++ & +++ \\
\hline $\mathrm{pH}$ regulation & +++ & +++ \\
\hline Biodiversity $^{\mathrm{a}}$ & + & +++ \\
\hline
\end{tabular}

\section{Other methods}

\begin{tabular}{l|l|l}
\hline Nitrogen fertilizer & a & e \\
\hline P, K mineral fertilizer & a & a (accepted are low soluble fertilizers) \\
\hline Herbicides & a & e \\
\hline Pesticides & a & e \\
\hline
\end{tabular}

Source: Authors compilation

$+=$ low $++=$ medium; $+++=$ high; / $=$ not applicable $;-=$ indicating intermediate position;

$0=$ not explicitly mentioned; $\mathrm{a}=$ accepted; $\mathrm{e}=$ excluded

a via biotope diversity

\section{Sustainable Intensification - Some Terminological Clarifications}

Most prominent agricultural production methods in recent years can be summarized as "Sustainable intensification (SI)," which is defined as meeting the growing demand for agricultural production while conserving land and other resources, "from the same area of land while reducing the negative environmental impacts and at the same time increasing contributions to natural capital and the flow of environmental services" (Khan et al. 2017). This term also accounts for the human condition, nutrition, and social equity. In their review, Smith et al. (2017) conclude, using a broad range of socio-, cultural, and socio-economic measures, that most current agricultural practices fall into this category. SI does not explicitly exclude any farming practice or requires an obligatory production framework, as, for example, the case for conservation agriculture with minimum tillage and mulching, or organic farming that excludes some farming and processing inputs. Mahon et al. (2017) conclude that SI is an oxymoron, underpinned by a productivist agenda, and that it is lacking a clear rationale. In their review, Xie et al. (2019) identify the 
reduction of yield gap as the main target of SI. But the intense use of mineral fertilizers is also not excluded (Holden 2018). Yet others, like Mdee et al. (2019), understand SI to be based on agroecological methods, or to classify integrated pest management as a core activity (Pretty and Bharucha 2015).

Definitions of CA do not explicitly exclude mineral fertilizers, herbicide and pesticide applications, but keep them at an option. Consequently, Vanlauwe et al. (2014b) summarize three conceptual pathways for intensification paradigms: (i) integrating soil fertility management ending up in conservation agriculture, (ii) push and pull systems (Khan et al. 2008b), and (iii) evergreen agriculture (agroforestry-based systems) (Garrity 2017). All of these systems contribute to high soil health status and productivity through somewhat different pathways. In contrast to the overall definition of SI, which includes overlaps of sustainable and ecological intensification (Wezel et al. 2015), these pathways are classified as being only part of ecological intensification and thus only cover partially what is discussed under the term SI.

Another concept, Climate Smart Agriculture (CSA), is defined by the FAO as "agriculture that sustainably increases productivity, resilience (adaptation), reduces/ removes greenhouse gases (mitigation), and enhances achievement of national food security and poverty reduction" (Nyasimi et al. 2014). CSA refers to food security and rural livelihood improvement through agricultural concepts that facilitate climate change adaptation and provide mitigation benefits (Scherr et al. 2012). Arable and plant cultivation methods applied refer to many of the field-based and farmbased sustainable agricultural land management practices identified as part of SI. As Zougmoré et al. (2016) suggest in their analysis of CCAM relevant approaches, CSA is a farming method like CA.

"Sustainable land (use) management (SLM)" as the last approach, which should be mentioned in this brief analysis, is a compilation of methods that summarizes many of the activities already introduced above. Gurtner et al. (2011) define SLM as "the adoption of land use systems that, through appropriate management practices, enables land users to maximize the economic and social benefits from the land whilst maintaining or enhancing the ecological support functions of the land resources." Arable and plant cultivation methods of SLM include soil fertility and crop management, soil erosion control measures, organic fertilization, minimum soil disturbance, and incorporation of residues, terraces, water harvesting and conservation, and agroforestry, grazing and forest management (Branca et al. 2013; Cordingley et al. 2015). But scholars highlight different specific methods. Dale (2010) defines SLM mainly as a technology approach to cope with erosion via mainly technical interventions and less one defined by crop-based systems.

\section{Conservation Agriculture}

Conservation agriculture (CA) integrates three principles (FAO) (www.fao.org/ag/ca): (i) avoiding or minimizing mechanical soil disturbance; (ii) enhancing and maintaining a permanent mulch cover with organic matter on the soil surface; and (iii) diversifying 
species (Kassam et al. 2017). Today CA is associated with three other agricultural production systems.

Push and pull system discussed as a core subsystem of CA, but also described as a climate smart technology that combines maize with undersown forage legumes and Napier grass, and with a minimum tillage approach (Midega et al. 2015), fulfills many of the ecological functions that contribute importantly to CCAM (Table 3) and enables sustainable cereal crop and livestock production intensification through ecosystem or agroecological approaches based on natural biological processes (Khan et al. 2014). In the face of CC, new drought-tolerant trap (e.g., Brachiaria cv. Mulato) and intercrop (drought-tolerant species of desmodium, e.g., D. intortum) plants have been studied to further develop the push and pull system (Khan et al. 2017). Another approach is Evergreen Conservation Agriculture, a subtype of CA, which focuses specifically on the integration of trees into crop and livestock production systems (Garrity 2017). Close to this system are agroforestry systems that include inter-planting of a broad range of leguminous shrubs (Pratt et al. 2002). For erosion control in combination with other conservation measures, for example, dense hedges of vetiver grass on contours are recommended (Bunderson et al. 2015).

The positive impacts of CA on yields are well documented (Mkonda and He 2017), with yield increases compared to traditional methods, for example, from $1 \mathrm{t}$ ha-1 to $3.5 \mathrm{tha}-1$ per cropping season (Khan et al. 2006) as well as increased milk production (Khan et al. 2008a; Khan et al. 2008b; Midega et al. 2014). As a result, $\mathrm{CA}$ is shown to contribute significantly to higher economic returns for the farmer (higher returns to both land and labor than conventional farmers' practices), thereby allowing reduced, and sometimes none, use of nitrogen fertilizers, herbicides, and pesticides. CA contributions towards carbon sequestration further underline their high contribution to CCAM (Gonzalez-Sanchez et al. 2019; Sommer et al. 2014).

\section{Organic Farming}

Organic farming (OF), as described by internationally accepted guidelines, is designed to be followed for farmers who are approved by certification processes and want to market their products as organic. OF also embodies a set of ethical principles that serve to orient all the subsystems of this agricultural production system. OF relies on (agro-) ecological processes, biodiversity at all levels (species, genotype, habitat, landscape...), and nutrient and carbon cycles, and high contributions to reduce agricultural GHG emissions (Scialabba and Müller-Lindenlauf 2010). All CCAM methods are recommended (see also FAO 2011), while other methods with often critical impact on the environment, but also for $\mathrm{CC}$ are limited (Table 3).

A key characteristic of organic farming is the focus on soil fertility, as a result of diversified crop rotations with forage legumes, catch crop and intercropping, and organic manure, which is the basis of a healthy and sustainable production (Meyer 2010). These diversified crop rotations largely replace the functions of excluded inputs like soluble mineral fertilizers, herbicides, and pesticides (Freyer 2019). 
Forage legume-based crop rotations, agroforestry, and nutrient and carbon recirculation are of high relevance. From a systems perspective, all of these methods must be implemented to enable a productive system. Tillage systems follow the idea to avoid the mix of fertile above ground soil layers with less fertile in lower layers. How far tillage intensity can be reduced depends on precrop - following crop relations, produced above and below ground biomass, organic manure type and amount, and the demand for weed control or to initiate mineralization processes, therefore cannot be generalized (Koepke 2003). At this point the difference between $\mathrm{OA}$ and $\mathrm{CA}$ becomes relevant which is the exclusion of many external inputs in the OA system. Functions of these excluded inputs must be partly taken over by the tillage system.

Other characteristics of $\mathrm{OA}$ are the inclusion of traditional knowledge, material, and methods (Müller and Davis 2009). Also, local seed collection and use is an intrinsic part of organic agriculture (Forster et al. 2012). Such seeds might be an advantage to adapt under certain climatic conditions and contribute to maintaining agro-biodiversity.

Africa hosts the majority of organic farms worldwide, with almost 2.1 million hectares of certified organic agricultural land (2017), and at least 815,000 producers (Willer and Lernoud 2019). But what is currently missing is an evaluation of the practices in these organic farming systems. Annual farm certification only partially informs the extent and quality of CCAM applications.

Moreover, research lacks a convincing organic systems approach. If trials include amounts of organic fertilizers that are going beyond the production capacity or what is currently known on that in practice, crop rotation principles are ignored, and alley cropping is not integrated (Adamtey et al. 2016; Musyoka et al. 2017). Such trials are of low relevance for identifying the real potential of OA to CCAM. This limited availability of research trials hinders a more in-depth assessment of the organic approach. Specifically, in comparison to CA, the gap is huge.

In African countries, OA is often equated with traditional practices - whatever they are - less mechanized, and minimum use of chemical fertilizers and pesticides. The low input systems neither fulfill the organic principles of health, ecology, fairness, and care, are not in line organic guidelines, nor would survive any organic farming certification process (Nalubwama et al. 2011).

\section{Discussion}

This section summarizes and provides an orientation to the interdependence of CCAM relevant methods. It informs the challenges of farmers to adopt and refers to farmers' perspectives, agroecological, social, livelihoods, and the surrounding conditions for implementing CCAM, as well as how to interpret communalities and differences between $\mathrm{CA}$ and $\mathrm{OA}$. 


\section{The Logic of CCAM Practices}

The interdependence of CCAM relevant methods is a key to understand their efficiency, success, or failure, not only for $\mathrm{CC}$, but also their impact on productivity. Methods can be classified into two levels:

- First level: Methods that provide biomass and nitrogen: Legume based Agroforestry systems, silvopastoral systems, forage legume-based/green manure cover crop, relay crop and intercrop-based crop rotation systems, and perennial productive high breed grasses.

- Second level: Methods that depend on the productivity and management of first level methods: mulching, manure and compost production, minimum tillage, $\mathrm{pH}$ regulation, biodiversity for pest and disease regulation.

Of course, isolating the yield effects of individual practices is complicated (Branca et al. 2013), but without optimal management of first level methods, second level methods cannot be activated or are weak in their performance. In other words, if methods in the first level are not well established, second level methods cannot be put in place. In organic farming, the application of CCAM relevant methods is obligatory to enable productivity with limited input from outside. Exclusion of one method would weaken the whole system. Of high relevance is the management quality of applied methods which allow that, even with very low amounts of residues, increases in the productivity with respect to conventional farming practices (Sommer et al. 2012). This fact is often overlooked. OA is very clear on this point there are no half measures - if so, the system would fail both in CCAM and in productivity.

\section{Barriers for Adoption CCAM from a Production Perspective}

In recent decades, extensive efforts to promote CA, CSA, or SLM have been undertaken. Despite extensive past efforts by governmental, nongovernmental, and research organizations to promote SLM to smallholder farmers in SSA, adoption remains low (Cordingley et al. 2015). What are the barriers to establish these methods from a production perspective?

- Crop specific: forage legume seeds, agroforestry seedlings and tree management, hybrid grass seeds, pasture seeds, weed control.

- Technically specific: soil tillage and seed technology, technology for cut and carry systems, stable construction, water management, storage, transportation and distribution of organic manure and compost.

Challenges to implement CCAM approaches are obviously not essentially different between CA and OA. The difference lies in the accessibility of nitrogen fertilizer, herbicides (Wall 2017), and pesticides that all can be applied as "emergency" 
methods in CA, while not in OA, These inputs provide CA farmers a set of methods that can be used when the crops are in a critical stage (lack of nitrogen, high weed pressure, expected outbreak of pest and diseases).

The differences between CA and OA can be identified largely in the so-called "other methods" (Table 3). Neither soluble mineral fertilizers nor herbicides and pesticides are allowed in either to bridge critical weather conditions, weed, or pest and disease development. Nitrogen fertilizer is the most relevant input with high impact on GHG emissions.

The application of these inputs is also controversially discussed in CA. While some argue that the three CA principles are sufficient to guide CA practices (Sommer et al. 2014; Wall 2017), Vanlauwe et al. (2014) identified a fourth principle, the application of mineral fertilizers. Many farmers believe that CA cannot be undertaken without specific inputs and tools, a message commonly conveyed to them by extension staff (e.g., hybrid seed, fertilizers, herbicides, knapsack sprayers, jab planters,...) (Bunderson et al. 2015). For farmers, the exclusion of "other methods" would limit the acceptance of CA and its scale on farms. Farmers also fear an increased abundance of termites and earthworms as harmful, whereas in fact they can have beneficial effects on the soil and crops (ibid). But there are also voices from the organic side that agriculture in Africa without herbicides and synthetic fertilizers is not possible and vote for their integration into the organic guidelines (Lotter 2015). The result would be simply CA. Other surveys report that farmers' perceptions indicate that $\mathrm{CA}$ without external inputs, such as fertilizers, herbicides, pesticides, or compost, can improve yields relative to conventional agriculture. This argument is supported by the observations of scientists that a large proportion of soils in sub-Saharan Africa can be described as nonresponsive (Tittonell and Giller 2013), in which mineral fertilizer applications do not result in higher crop yields, while already the application of the three CA principles led to serious higher yields in comparison to the conventional input driven approach (Ngwira et al. 2013; Thierfelder and Wall 2010). Also, effective weed management is possible without the use of herbicides, since all three CA practices contribute to integrated weed control, also experienced in organic farming, if crop rotation and weed management are organized following latest knowledge. These observations are a clear reference about the OA system that also builds besides other methods on the three CA principles. These experiences are also showing that subsidizing of inputs is not a necessary precondition to CA use and uptake (Bunderson et al. 2015; Lalani et al. 2017).

According to FAO (2012), 80\% of all farms in Africa have an agricultural area of $<2$ ha. These fragmented small land holdings preclude the effectiveness of large machinery in fieldwork, specifically for cut and carry systems, mulch-seeding systems/zero-tillage direct seeders, or the distribution of farm yard manure or mulch from outside the field, or from alleys (Sims et al. 2017; Sommer et al. 2014). In contrast, Lalani et al. (2017) observed that manual forms of CA can be attractive for farmers, particularly those with very small plots of land ( 0.5 ha or less), observing that mulching systems can reduce weed pressure. 
Labor for biomass management is discussed as a barrier to the adoption of some CA methods, while others like seed varieties that are drought tolerant and early maturing are classified as the most suited technologies for smallholder farmers to respond react to CC (Senyolo et al. 2018). To define the CA approach only with drought resistant seed material, optimized irrigation and mineral fertilizers fail the overall idea, which could be also titled with "CA by default" or a conventionalized $\mathrm{CA}$; of course it is less complex to apply a hand full of fertilizers and a herbicide instead of developing diversified crop rotation, mulching, and agroforestry systems.

A further barrier of CA/OA systems with the CCAM approaches is that they cannot be put in place in one season. Often the starting points for transforming the system are poor soil fertility, land degradation, pests, and erratic rainfall that are challenging the adoption (Sietz and Van Dijk 2015). It is therefore not only about implementing new farming methods, but also to "repair" the damaged natural system. There is a conversion period of 2 to 3 years as it is also for OA, where farmers primarily have to invest in the transformation of the system. This requires a period of labor and financial investment, and patience by farmers until trade-offs of the new system become visible in an increase of productivity (Lalani et al. 2017).

In addition to these relevant hurdles, it is to keep in mind that weed and pest and disease control are a challenge for all farmers, irrespective of the CCAM methods, and not specific for $\mathrm{CA} / \mathrm{OA}$, like diversified crop rotations, in comparison to maize monocropping (Thierfelder et al. 2013; Thierfelder and Wall 2010); however, the high increase of pest and diseases provoked by monocropping and biodiversity poor landscapes underlines that farmers on the long run have no other choice than to modify their system, independent from CC.

\section{Markets, Policies, and Education for a Diversified Production}

The implementation process of CCAM methods still lacks a clear conceptual understanding (Partey et al. 2018). The poor understanding of CA/OA, its CCAM methods, and suspected contradictions over what it means reflect the absence of an overall educational training program for teachers, extension officers, and students (Bunderson et al. 2015). Field trials should not lack of first level CCAM approaches (see the example of (Thierfelder et al. 2013, 2016); without training programs for farmers, chances for successful adoption of CCAM will continue slim (Erenstein et al. 2012).

Diversified production is also not possible without a policy and market enabling crop diversity and rewarding the contributions toward biodiversity and CCAM. Sustainable out-scaling of CCAM and to achieve large-scale landscape adoption depends on linkage to functional markets for inputs and outputs (Sommer et al. 2014). There is need for more attention via policy and extension on value chains, and more focused development resources from donors, governments, nongovernmental organizations (NGOs), and national and international research and development organizations to support participatory dissemination and upscaling of CCAM approaches (Friedrich et al. 2012). Investment policies should focus along value 
chains from technology at farm level, up to processing, and the availability of specifically forage legume seeds and tree seedlings.

Certification, that is, labeling of CCAM based agriculture, might be an option to support their implementation if linked with subsidies. In case of OA certification, schemes protecting the production status is currently only a half solution to increase the share of CCAM approaches in practice, due to the fact that only farmers with products for export are able to partly cover the relatively high certification costs. For local markets, certified products with a premium price are not adapted to the economic conditions of local population. Apart from specific investment costs, the successful implementation of CCAM methods would increase production and thus farmers income, making additional price premiums less important. An ecosystem services-based payment scheme might be an option; however, the administrative costs can be currently higher than the money reaching the farmers pocket.

To make an impact, integrated participatory catchment strategies are expected to be most efficient in terms of adoption of CCAM methods, via technology, advisory and financial support, and the implementation of an impact monitoring (Scherr et al. 2012).

Sensitivity must be given of the vulnerable and marginalized (women and poorer households, for instance) to avoid the exclusion and a social gradient (Feder et al. 2010). Multiple communication tools are discussed as a precondition for successful implementation of CCAM (Leeuwis and Aarts 2011). To bring together broad experience for learning and encouraging innovation, communication platforms should be established including farmers' organizations, advisory services, and universities. Social acceptance by referents, and shared learning processes, plays a key role in this regard (Lalani et al. 2017).

National policies have to frame this process, for example, to strengthen the establishment of a seed and seedling sector specifically for forage legumes and legume trees, while regional land locally sensitive policy instruments serve for finetuning of product specific value chains (Zougmoré et al. 2016).

\section{Conclusions}

This chapter summarizes the status and potential of smallholder farmers' application of CCAM practices and some observations on the institutional environment, with reference mainly to the subtropical/tropical environments of East African smallholder farming.

Lessons learned are that many CCAM relevant arable and plant cultivation methods are available, but most of these are still not in place. It is obvious that all CCAM methods contribute to an increase of productivity, with minor exceptions, where systems need further development.

With respect to agricultural production systems where the integration of CCAM methods is far advanced, conservation agriculture (CA) builds on the use of farm inputs including nitrogen fertilizer, soluble mineral fertilizers, herbicides, and chemical pesticides, while organic agriculture (OA) excludes these inputs. To what extent 
these inputs are a precondition for successful CA management is a matter of controversy. CCAM methods are practically similar in both approaches - CA and $\mathrm{OA}$ - while the degree of their implementation and favored methods might be different.

The amount of biomass production and nitrogen by nitrogen fixing crops is a key driver of CCAM and an increase of farm productivity. Both can serve as general indicators to assess farms, that is, catchments in their progress to cope with $\mathrm{CC}$ and to boost productivity, while it is less the share of mineral fertilizer. Most relevant crop groups with highest impact are forages legumes, forage grain legumes, and leguminous alley crops, but also biomass rich hybrid grasses, that profit indirectly from the forage legume nitrogen, for example, via slurry. These crop groups are the ones that increase soil fertility, reduce soil erosion and increase water holding capacity, biological pest and disease control, provide the feed biomass for animal husbandry systems, and guarantee an increase of cash crop yield and quality. Critical is the low supply of specifically forage legumes in seed markets.

There are still open questions, specifically concerning the GHG of mulching systems, pest and disease management and weed control, adapted technology for small scale farming and catchment strategies for a synergetic and efficient management. But those aspects are more part of a site and farm specific fine tuning than of fundamental lack of knowledge, which currently characterizes one of the main innovation barriers.

The dramatic negative trends of soil quality, biodiversity, and CC speak a clear language that the agricultural systems must bid farewell to one-sided systems. There is a need for a fundamental change, that is, resetting of the current farming practices, in other words, adaptation is no longer the appropriate term but the comprehensive transformation of the farming system as a whole. This is only possible if there is an enabling institutional and policy environment that supports agricultural research, advisory services, and education oriented to farmers' needs to adapt their farming system, making it more robust against drought and floods through the establishment of biomass and nitrogen producing cropping systems, and is reducing the farm specific negative impact on CC. This transformation process depends on assuring that best practices, adapted to local conditions, can demonstrate a reduction of labor, and a serious increase of farm income. It is recommended to apply a more systemic view in developing farming systems and related value chains, instead of focusing on single methods, that is, products. Transformation towards biodiverse crop rotations and biomass management also asks for the respective markets, consumer demands, and processing units, for example, for an increased milk production as a result of increased forage production, a dairy structure, and adaptions, that is, transformations of human diets. These final remarks clearly inform about the need for systemic transformation of food systems for successful CCAM management. 


\section{References}

Achieng J, Ouma G, Odhiambo G, Muyekho F (2010) Effect of farmyard manure and inorganic fertilizers on maize production on Alfisols and Ultisols in Kakamega, western Kenya. Agric Biol J N Am 1(4):430-439

Adamtey N, Musyoka MW, Zundel C, Cobo JG, Karanja E, Fiaboe KK, ... Berset E (2016) Productivity, profitability and partial nutrient balance in maize-based conventional and organic farming systems in Kenya. Agric Ecosyst Environ 235:61-79

Awazi NP, Tchamba MN (2019) Enhancing agricultural sustainability and productivity under changing climate conditions through improved agroforestry practices in smallholder farming systems in Sub-Saharan Africa. Afr J Agric Res 14(7):379-388

Branca G, Lipper L, McCarthy N, Jolejole MC (2013) Food security, climate change, and sustainable land management. A review. Agron Sustain Dev 33(4):635-650

Broom D, Galindo F, Murgueitio E (2013) Sustainable, efficient livestock production with high biodiversity and good welfare for animals. Proc R Soc B Biol Sci 280(1771):20132025

Bunch R (2017) How can we cover millions of hectares with conservation agriculture in Africa. Conservation agriculture for Africa: building resilient farming systems in a changing climate. CABI: Boston, 139

Bunderson WT, Jere ZD, Thierfelder C, Gama M, Mwale BM, Ng'oma SW, ... Mkandawire O (2015) Implementing the principles of conservation agriculture in Malawi: crop yields and factors affecting adoption. Conservation Agriculture for Africa: Building Resilient Farming Systems in a Changing Climate

Cordingley JE, Snyder KA, Rosendahl J, Kizito F, Bossio D (2015) Thinking outside the plot: addressing low adoption of sustainable land management in sub-Saharan Africa. Curr Opin Environ Sustain 15:35-40

Dale D (2010) Sustainable land management technologies and approaches in Ethiopia. SLMP. Natural Resources Management Sector, MOARD, Addis Ababa

Dupar M (2019) Intergovernmental Panel on Climate Change (2019). Climate Change and Land: An IPCC Special Report on climate change, desertification, land degradation, sustainable land management, food security, and greenhouse gas fluxes in terrestrial ecosystems. Rome

Elwell H, Stocking M (1988) Loss of soil nutrients by sheet erosion is a major hidden farming cost. Zimb Sci News 22(7):8

Erenstein O, Sayre K, Wall P, Hellin J, Dixon J (2012) Conservation agriculture in maize-and wheat-based systems in the (sub) tropics: lessons from adaptation initiatives in South Asia, Mexico, and Southern Africa. J Sustain Agric 36(2):180-206

FAO (2011) Save and grow - a policymaker's guide to the sustainable intensification of smallholder crop production. FAO, Rome

FAO (2012) The State of Food and Agriculture. FAO, Rome

Feder G, Anderson JR, Birner R, Deininger K (2010) Promises and realities of community-based agricultural extension. In Community, Market and State in Development. Springer, New York (pp. 187-208)

Forster D, Adamtey N, Messmer MM, Pfiffner L, Baker B, Huber B, Niggli U (2012) Organic agriculture - driving innovations in crop research. In Agricultural sustainability-progress and prospects in crop research. Elsevier, pp 21-46

Franzel S, Carsan S, Lukuyu B, Sinja J, Wambugu C (2014) Fodder trees for improving livestock productivity and smallholder livelihoods in Africa. Curr Opin Environ Sustain 6:98-103

Freyer B (2019) The role of the crop rotation in organic farming. In: Köpke U (ed) Improving organic crop cultivation. Burleigh Dodds Science Publishing Limited, Cambridge, MA, pp 547-568

Friedrich T, Derpsch R, Kassam A (2012) Overview of the global spread of conservation agriculture. Field actions science reports. J Field Actions (Special Issue 6), p. 1-7

Garrity DP (2017) How to make conservation agriculture evergreen. In Kassam AH, Mkomwa S, Friedrich T (eds) Conservation agriculture for Africa. Building resilient farming systems in a changing climate. CABI: Boston. pp 167-182 
Ghimire SR, Njarui DM, Mutimura M, Cardoso Arango JA, Johnson L, Gichangi E, ... Rao IM (2015) Climate-smart Brachiaria for improving livestock production in East Africa: Emerging opportunities. Paper presented at the Sustainable use for grassland resources for forage production, Range Management Society of India, Jhansi, India

Giller KE, Corbeels M, Nyamangara J, Triomphe B, Affholder F, Scopel E, Tittonell P (2011) A research agenda to explore the role of conservation agriculture in African smallholder farming systems. Field Crop Res 124(3):468-472

Gómez-Carabalí A, Idupulapati Madhusudana R, Ricaute J (2010) Differences in root distribution, nutrient acquisition and nutrient utilization by tropical forage species grown in degraded hillside soil conditions ${ }^{1}$. Acta Agronómica 59(2):197-210

Gonzalez-Sanchez EJ, Veroz-Gonzalez O, Conway G, Moreno-Garcia M, Kassam A, Mkomwa S, ... Carbonell-Bojollo R (2019) Meta-analysis on carbon sequestration through conservation agriculture in Africa. Soil Tillage Res 190:22-30

Grant MJ, Booth A (2009) A typology of reviews: an analysis of 14 review types and associated methodologies. Health Inform Libr J 26(2):91-108

Gurtner M, Liniger H, Studer R, Hauert C (2011) Sustainable land management in practice: Guidelines and best practices for Sub-Saharan Africa. FAO, Rome

Hillocks R (1998) The potential benefits of weeds with reference to small holder agriculture in Africa. Integr Pest Manag Rev 3(3):155-167

Hobbs PR, Govaerts B (2010) How conservation agriculture can contribute to buffering climate change. Climate change and crop production. CABI, Cambridge, p. 177-199

Holden ST (2018) Fertilizer and sustainable intensification in Sub-Saharan Africa. Glob Food Sec $18: 20-26$

IPCC (2018) Special Report Climate Change and Land. IPCC, Rome

Kassam A, Basch G, Friedrich T, Gonzalez E, Trivino P, Mkomwa S (2017) Mobilizing greater crop and land potentials sustainably. Hung Geograph Bull 66(1):3-11

Khan Z, Pickett JA, Wadhams LJ, Hassanali A, Midega CA (2006) Combined control of Striga hermonthica and stemborers by maize-Desmodium spp. intercrops. Crop Prot 25(9):989-995

Khan Z, Amudavi DM, Midega CA, Wanyama JM, Pickett JA (2008a) Farmers' perceptions of a 'push-pull'technology for control of cereal stemborers and Striga weed in western Kenya. Crop Prot 27(6):976-987

Khan Z, Midega CA, Amudavi DM, Hassanali A, Pickett JA (2008b) On-farm evaluation of the 'push-pull'technology for the control of stemborers and striga weed on maize in western Kenya. Field Crop Res 106(3):224-233

Khan Z, Midega CA, Pittchar JO, Murage AW, Birkett MA, Bruce TJ, Pickett JA (2014) Achieving food security for one million sub-Saharan African poor through push-pull innovation by 2020 . Philos Trans R Soc B: Biol Sci 369(1639):20120284

Khan Z, Midega CA, Hooper A, Pickett J (2016) Push-pull: chemical ecology-based integrated pest management technology. J Chem Ecol 42(7):689-697

Khan Z, Midega CA, Pittachar J, Murage A, Pickett J (2017) Climate-smart push-pull: a conservation agriculture technology for food security and environmental sustainability in Africa. In: Conservation agriculture for Africa: building resilient farming systems in a changing climate. BABI, Wallingford, pp 151-166

Koepke U (2003) Conservation agriculture with and without use of agrochemicals. Paper presented at the proceedings of the 2nd world congress on conservation agriculture, Iguassu Falls, Paraná, Brazil

Kumar S, Meena RS, Lal R, Yadav GS, Mitran T, Meena BL, ... Ayman E-S (2018) Role of legumes in soil carbon sequestration. In Legumes for Soil Health and Sustainable Management. Springer. New York (pp. 109-138)

Lalani B, Dorward P, Kassam AH, Dambiro J (2017) Innovation systems and farmer perceptions regarding conservation agriculture in Cabo Delgado, Mozambique. AH Kassam, S. Mkomwa, $\&$ T. Friedrich, Conservation Agriculture for Africa: Building resilient farming systems in a changing climate, 100-126. CABI, Boston 
Lasco RD, Delfino RJP, Catacutan DC, Simelton ES, Wilson DM (2014) Climate risk adaptation by smallholder farmers: the roles of trees and agroforestry. Curr Opin Environ Sustain 6:83-88

Leeuwis C, Aarts N (2011) Rethinking communication in innovation processes: creating space for change in complex systems. J Agric Educ Extension 17(1):21-36

Lotter D (2015) Facing food insecurity in Africa: why, after 30 years of work in organic agriculture, I am promoting the use of synthetic fertilizers and herbicides in small-scale staple crop production. Agric Hum Values 32(1):111-118

Mahon N, Crute I, Simmons E, Islam MM (2017) Sustainable intensification-“oxymoron” or "third-way"? A systematic review. Ecol Indic 74:73-97

Majumder K (2015) A young researcher's guide to a systematic review. Editage, Japan

Mason-D'Croz D, Sulser TB, Wiebe K, Rosegrant MW, Lowder SK, Nin-Pratt A, ... Cenacchi N (2019) Agricultural investments and hunger in Africa modeling potential contributions to SDG2-Zero Hunger. World Dev 116:38-53

Mbow C, Smith P, Skole D, Duguma L, Bustamante M (2014) Achieving mitigation and adaptation to climate change through sustainable agroforestry practices in Africa. Curr Opin Environ Sustain 6:8-14

Mchunu CN, Lorentz S, Jewitt G, Manson A, Chaplot V (2011) No-till impact on soil and soil organic carbon erosion under crop residue scarcity in Africa. Soil Sci Soc Am J 75(4):15031512

Mdee A, Wostry A, Coulson A, Maro J (2019) A pathway to inclusive sustainable intensification in agriculture? Assessing evidence on the application of agroecology in Tanzania. Agroecol Sustain Food Syst 43(2):201-227

Meyer R (2010) Low-input intensification in agriculture chances for small-scale farmers in developing countries. Gaia-Ecol Perspect Sci Soc 19(4):263-268

Midega CA, Salifu D, Bruce TJ, Pittchar J, Pickett JA, Khan ZR (2014) Cumulative effects and economic benefits of intercropping maize with food legumes on Striga hermonthica infestation. Field Crop Res 155:144-152

Midega CA, Bruce TJ, Pickett JA, Pittchar JO, Murage A, Khan ZR (2015) Climate-adapted companion cropping increases agricultural productivity in East Africa. Field Crop Res $180: 118-125$

Mkonda MY, He X (2017) Conservation agriculture in Tanzania. In: Sustainable agriculture reviews. Springer, Berlin, pp 309-324

Monegat C (1991) Plantas de cobertura del suelo: características y manejo en pequeñas propiedades. Universidad Nacional Agraria, (UNA), Nicaragua Centro Nacional de Investigación y Documentación Agropecuaria, (CENIDA)

Müller A, Davis JS (2009) Reducing global warming: the potential of organic agriculture. FiBL, Frick, Switzerland

Murthy IK, Gupta M, Tomar S, Munsi M, Tiwari R, Hegde G, Ravindranath N (2013) Carbon sequestration potential of agroforestry systems in India. J Earth Sci Clim Chang 4(1):1-7

Murthy IK, Dutta S, Vinisha V (2016) Impact of agroforestry sytems on ecological and socioeconomic systems: a review. Glob J Sci Front Res: H Environ Earth Sci 16(5):15-27

Musyoka MW, Adamtey N, Muriuki AW, Cadisch G (2017) Effect of organic and conventional farming systems on nitrogen use efficiency of potato, maize and vegetables in the Central highlands of Kenya. Eur J Agron 86:24-36

Nalubwama SM, Mugisha A, Vaarst M (2011) Organic livestock production in Uganda: potentials, challenges and prospects. Trop Anim Health Prod 43(4):749-757

Nandwa S, Obanyi S, Mafongoya P (2011) Agro-ecological distribution of legumes in farming systems and identification of biophysical niches for legumes growth. In: Fighting poverty in Sub-Saharan Africa: the multiple roles of legumes in integrated soil fertility management. Springer, Dordrecht, pp 1-26

Ndambi OA, Pelster DE, Owino JO, De Buisonje F, Vellinga T (2019) Manure management practices and policies in sub-Saharan Africa: implications on manure quality as a fertilizer. Front Sustain Food Syst 3:29 
Ngwira AR, Thierfelder C, Lambert DM (2013) Conservation agriculture systems for Malawian smallholder farmers: long-term effects on crop productivity, profitability and soil quality. Renew Agric Food Syst 28(4):350-363

Nyasimi M, Amwata D, Hove L, Kinyangi J, Wamukoya G (2014) Evidence of impact: climatesmart agriculture in Africa

Ochieng SA, Waiswa DC (2019) Pastoral education: the missing link in Uganda education system. Educ Res Rev 14(7):240-253

Partey ST, Zougmoré RB, Ouédraogo M, Campbell BM (2018) Developing climate-smart agriculture to face climate variability in West Africa: challenges and lessons learnt. J Clean Prod 187:285-295

Porter JR, Challinor AJ, Henriksen CB, Howden SM, Martre P, Smith P (2019) Invited review: intergovernmental panel on climate change, agriculture, and food - a case of shifting cultivation and history. Glob Chang Biol 25(8):2518-2529

Powlson DS, Stirling CM, Jat ML, Gerard BG, Palm CA, Sanchez PA, Cassman KG (2014) Limited potential of no-till agriculture for climate change mitigation. Nat Clim Chang 4(8):678-683

Pratt J, Henry E, Mbeza H, Mlaka E, Satali L (2002) Malawi agroforestry extension project marketing \& enterprise program, main report. Malawi Agroforestry 47:139

Pretty J, Bharucha ZP (2015) Integrated pest management for sustainable intensification of agriculture in Asia and Africa. Insects 6(1):152-182

Reicosky DC (2015) Conservation tillage is not conservation agriculture. J Soil Water Conserv 70 (5):103A-108A

Rusinamhodzi L, Corbeels M, Nyamangara J, Giller KE (2012) Maize-grain legume intercropping is an attractive option for ecological intensification that reduces climatic risk for smallholder farmers in Central Mozambique. Field Crop Res 136:12-22

Sarvade S, Upadhyay V, Agrawal S (2019) Quality fodder production through silvo-pastoral system: a review. In: Dev I, Ram A, Kumar N, Singh R, Kumar D, Uthappa AR, Handa AK, Chaturvedi OP (eds) Agroforestry for climate resilience and rural livelihood. Scientific Publishers, Jodhpur, pp 345-359

Scherr SJ, Shames S, Friedman R (2012) From climate-smart agriculture to climate-smart landscapes. Agric Food Security 1(1):12

Schroth G, Balle P, Peltier R (1995) Alley cropping groundnut with Gliricidia sepium in Cote d'Ivoire: effects on yields, microclimate and crop diseases. Agrofor Syst 29(2):147-163

Schultze-Kraft R, Rao IM, Peters M, Clements RJ, Bai C, Liu G (2018) Tropical forage legumes for environmental benefits: an overview. Trop Grasslands-Forrajes Tropicales 6(1):1-14

Scialabba NE-H, Müller-Lindenlauf M (2010) Organic agriculture and climate change. Renew Agric Food Syst 25(2):158-169

Scopel E, Triomphe B, Ribeiro MdS, Séguy L, Denardin JE, Kochann R (2004) Direct seeding mulch-based cropping systems (DMC) in Latin America. Paper presented at the new directions for a diverse planet: proceedings for the 4th international crop science congress, Brisbane

Senyolo MP, Long TB, Blok V, Omta O (2018) How the characteristics of innovations impact their adoption: an exploration of climate-smart agricultural innovations in South Africa. J Clean Prod 172:3825-3840

Sheaffer CC, Seguin P (2003) Forage legumes for sustainable cropping systems. J Crop Prod 8 $(1-2): 187-216$

Sietz D, Van Dijk H (2015) Land-based adaptation to global change: what drives soil and water conservation in western Africa? Glob Environ Chang 33:131-141

Sims B, Kienzle J, Mkomwa S, Friedrich T, Kassam A (2017) Mechanization of smallholder conservation agriculture in Africa; contributing resilience to precarious systems. Conservation Agriculture for Africa. Building Resilient Farming Systems in a Changing Climate; Kassam, AH, Mkomwa, S., Friedrich, T., Eds, 183-213. CABI, Boston

Smith A, Snapp S, Chikowo R, Thorne P, Bekunda M, Glover J (2017) Measuring sustainable intensification in smallholder agroecosystems: a review. Glob Food Sec 12:127-138 
Sommer R, Piggin C, Haddad A, Hajdibo A, Hayek P, Khalil Y (2012) Simulating the effects of zero tillage and crop residue retention on water relations and yield of wheat under rainfed semiarid Mediterranean conditions. Field Crop Res 132:40-52

Sommer R, Thierfelder C, Tittonell P, Hove L, Mureithi J, Mkomwa S (2014) Fertilizer use should not be a fourth principle to define conservation agriculture: response to the opinion paper of Vanlauwe et al. (2014) 'A fourth principle is required to define conservation agriculture in subSaharan Africa: the appropriate use of fertilizer to enhance crop productivity'. Field Crops Res 169:145-148

Teenstra E, de Buisonjé F, Ndambi A, Pelster D (2015) Manure Management in the (Sub-) Tropics: training manual for extension workers. Wageningen UR (University \& Research centre) Livestock Research, Livestock Research Report 919

Tesfa A, Mekuriaw S (2014) The effect of land degradation on farm size dynamics and croplivestock farming system in ethiopia: A Review. Open Journal of Soil Science, 2014, p. 1-5

Thierfelder C, Wall P (2010) Rotation in conservation agriculture systems of Zambia: effects on soil quality and water relations. Exp Agric 46(3):309-325

Thierfelder C, Cheesman S, Rusinamhodzi L (2013) Benefits and challenges of crop rotations in maize-based conservation agriculture (CA) cropping systems of southern Africa. Int J Agric Sustain 11(2):108-124

Thierfelder C, Bunderson WT, Jere ZD, Mutenje M, Ngwira A (2016) Development of conservation agriculture (CA) systems in Malawi: lessons learned from 2005 to 2014. Exp Agric 52(4):579-604

Thomas RJ, Asakawa N (1993) Decomposition of leaf litter from tropical forage grasses and legumes. Soil Biol Biochem 25(10):1351-1361

Tittonell P, Giller KE (2013) When yield gaps are poverty traps: the paradigm of ecological intensification in African smallholder agriculture. Field Crop Res 143:76-90

Traill S, Bell LW, Dalgliesh NP, Wilson A, Ramony L-M, Guppy C (2018) Tropical forage legumes provide large nitrogen benefits to maize except when fodder is removed. Crop Pasture Sci 69 (2):183-193

Tully K, Sullivan C, Weil R, Sanchez P (2015) The state of soil degradation in Sub-Saharan Africa: baselines, trajectories, and solutions. Sustainability 7(6):6523-6552

Vanlauwe B, Aihou K, Tossah B, Diels J, Sanginga N, Merckx R (2005) Senna siamea trees recycle $\mathrm{Ca}$ from a Ca-rich subsoil and increase the topsoil $\mathrm{pH}$ in agroforestry systems in the West African derived savanna zone. Plant Soil 269(1-2):285-296

Vanlauwe B, Coyne D, Gockowski J, Hauser S, Huising J, Masso C, ... Van Asten P (2014a) Sustainable intensification and the African smallholder farmer. Curr Opin Environ Sustain 8:15-22

Vanlauwe B, Wendt J, Giller KE, Corbeels M, Gerard B, Nolte C (2014b) A fourth principle is required to define conservation agriculture in sub-Saharan Africa: the appropriate use of fertilizer to enhance crop productivity. Field Crop Res 155:10-13

Wall P (2017) Conservation Agriculture: Growing More with Less-the Future of Sustainable Intensification. Conservation agriculture for Africa, CABI, Boston. p. 30-40

Wezel A, Soboksa G, McClelland S, Delespesse F, Boissau A (2015) The blurred boundaries of ecological, sustainable, and agroecological intensification: a review. Agron Sustain Dev 35 (4):1283-1295

Wilkins RJ (2008) Eco-efficient approaches to land management: a case for increased integration of crop and animal production systems. Philos Trans R Soc B: Biol Sci 363(1491):517-525

Willer H, Lernoud J (2019) The world of organic agriculture. Statistics and emerging trends 2019: Research Institute of Organic Agriculture FiBL and IFOAM Organics International

Wilson G, Kang B, Mulongoy K (1986) Alley cropping: trees as sources of green-manure and mulch in the tropics. Biol Agric Horticulture 3(2-3):251-267

Wynants M, Kelly C, Mtei K, Munishi L, Patrick A, Rabinovich A, ... Boeckx P (2019) Drivers of increased soil erosion in East Africa's agropastoral systems: changing interactions between the social, economic and natural domains. Regional Environmental Change, 19, p. 1909-1921

Xie H, Huang Y, Chen Q, Zhang Y, Wu Q (2019) Prospects for agricultural sustainable intensification: a review of research. Land 8(11):157 
Zougmoré R, Partey S, Ouédraogo M, Omitoyin B, Thomas T, Ayantunde A, ... Jalloh A (2016) Toward climate-smart agriculture in West Africa: a review of climate change impacts, adaptation strategies and policy developments for the livestock, fishery and crop production sectors. Agric Food Security 5(1):26

Zougmoré RB, Partey ST, Ouédraogo M, Torquebiau E, Campbell BM (2018) Facing climate variability in sub-Saharan Africa: analysis of climate-smart agriculture opportunities to manage climate-related risks. Cahiers Agricultures (TSI) 27(3):1-9

Open Access This chapter is licensed under the terms of the Creative Commons Attribution 4.0 International License (http://creativecommons.org/licenses/by/4.0/), which permits use, sharing, adaptation, distribution and reproduction in any medium or format, as long as you give appropriate credit to the original author(s) and the source, provide a link to the Creative Commons license and indicate if changes were made.

The images or other third party material in this chapter are included in the chapter's Creative Commons license, unless indicated otherwise in a credit line to the material. If material is not included in the chapter's Creative Commons license and your intended use is not permitted by statutory regulation or exceeds the permitted use, you will need to obtain permission directly from the copyright holder.

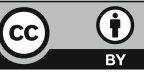

